\title{
Choosing A University: Applying Student Experiences To Managerial Accounting Concepts
}

Barbara Reider, University of Montana, USA

Belva Jones, University of Montana, USA

Barbara Chaney, University of Montana, USA

Kristen Sohlberg, University of Montana, USA

\begin{abstract}
This case allows students to apply their recent university-selection experience to managerial accounting concepts. For some students, the decision to attend a particular university is easy; for others, the number of factors to consider may appear overwhelming. We provide a realistic scenario for making this decision that focuses on both financial considerations and important qualitative aspects of college. Our goal is to provide students a concrete example that allows them to utilize their experience in making this decision with the cost concepts necessary in understanding managerial accounting. Our fictional character, Amy, is choosing between an instate public university, an out-of-state public university, and a private college in the Pacific Northwest. Instructors can use this case to reinforce cost concepts, cost behavior, and relevant costs.
\end{abstract}

Keywords: cost concepts, cost behavior, relevant range

\section{INTRODUCTION}

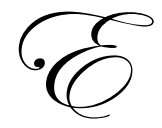

ach business student at The University of Montana is required to complete the managerial accounting course with at least a grade of $\mathrm{C}$ before he may enroll in upper-division business courses. Since $75 \%$ of our students are not accounting majors, they sometimes view the course as a hurdle to jump before taking their "real" courses in their chosen majors.

Many Montana students struggle with cost concepts, cost behavior, and relevant costs when our textbook authors (Garrison, Noreen, and Brewer, 2008) provide manufacturing examples. The Montana economy is heavily service-based with very few manufacturing facilities, making the textbook examples abstract. However, our students are very cognizant of the tuition and fees the university assesses them each term. The Accounting Education Change Commission (1992) recommends that students in general accounting courses gain the ability to confront unstructured problems and that faculty recognize the value of using cases and simulations.

The purpose of this case is to provide a realistic scenario for learning cost concepts, cost behavior, and relevant cost topics. The scenario we create should be familiar to students who have recently made the decision to attend a particular college or university. We ask students to consider not only their own costs in making a decision, but also to identify the expenses that universities must cover.

\section{CASE}

Amy Baldwin is excited to be graduating in May from Spokane High School in the state of Washington. While she has enjoyed her time in high school, she is looking forward to going to college. In high school, Amy was an honor roll student and involved in student government. She played junior varsity basketball and ran cross- 
country. Outside of school Amy enjoys skiing with her family, kayaking, and leading her church youth group's service activities. She regularly volunteers at the local humane society and at a community homeless shelter.

Many of Amy's friends have already decided where they plan to attend college in the fall. Some will attend state schools in Washington. Others will go to public schools in nearby states. A few friends have chosen private institutions. Amy cannot make up her mind between her top three choices: Washington State University (WSU), the University of Montana (UM), and Gonzaga University (GU).

Amy's parents suggested to her that she create an academic year budget for each of the institutions she is considering. Amy obtained estimates of the cost of tuition, fees, room, board, and books from the institutions' web sites. She estimated the cost of travel to and from school each semester by considering the distance of the institution from her parents' home.

Amy is surprised to find that the universities' cost schedules for tuition and fees are often quite complicated. The total amount charged depended upon a number of factors, including state residency and credit hour enrollment. If the institutions' tuition schedules were confusing, the fee schedules were incomprehensible! She plans to enroll as a full-time student. With a little research, Amy finds that a few universities consider undergraduate students as "full-time" if they enroll for 12 credit hours each semester. However, most institutions consider a full load to be 15 credit hours.

WSU charges tuition per credit hour for enrollment under 10 hours and over 18 hours. However, if a student enrolls between 10 and 18 credit hours, WSU charges a flat $\$ 6,290$. Fees at the school are $\$ 576$ for each student (see Table 1 Panel A).

At Gonzaga, a student is charged tuition of $\$ 26,120$ if she enrolls between 12 and 18 credit hours. Tuition includes student activity fees at GU. There are limited mandatory fees that total $\$ 400$. In addition, there are numerous department and course fees at GU (see Table 1 Panel B).

The University of Montana charges tuition per credit hour for students enrolled for fewer than 12 credit hours. Beyond 12 credit hours, students pay \$5,609 for the "flat spot." UM has an extensive and complicated schedule of fees; some fees are charged per credit hour up to 7 hours, while other fees are charged per credit hour up to 12 hours. Therefore, fees depend upon enrollment, just like tuition (see Table 1 Panel C).

Because Amy's top three choices are very different types of schools, Amy finds that their pricing policies vary drastically. She learns that public universities charge out-of-state students more tuition than students who are residents of the state. This seemed particularly unfair to her and she wonders why public schools would discriminate against out-of-state students. Amy also finds that private institutions charge significantly more tuition than public institutions. This confuses Amy because she assumed that the cost of educating a student would be the same for the different types of institutions. Therefore, she believes tuition should not differ so radically.

WSU and GU assess very few fees while UM assesses many. WSU and GU assess a flat fee for every student while UM varies the fees according to the number of hours a student enrolls. In addition, GU charges few fees at the institution level, but charges numerous department and course fees. Because Amy is not sure what major she will choose or which courses she will take, she does not include any of the department and course fees in her budget.

Amy summarizes the results of her research in an academic year budget for each of the three institutions she is considering. She is surprised that an academic year at an out-of-state public university would cost less than at an in-state school. This is the result of an interesting scholarship program called the Western Undergraduate Exchange that reduces nonresident tuition for excellent applicants from nearby western states. Amy is also surprised to learn that an education at Gonzaga would cost more $(\$ 27,470)$ than either alternative, even if she saves room and board by living at home. Amy is prepared to present the results of her research to her parents. 


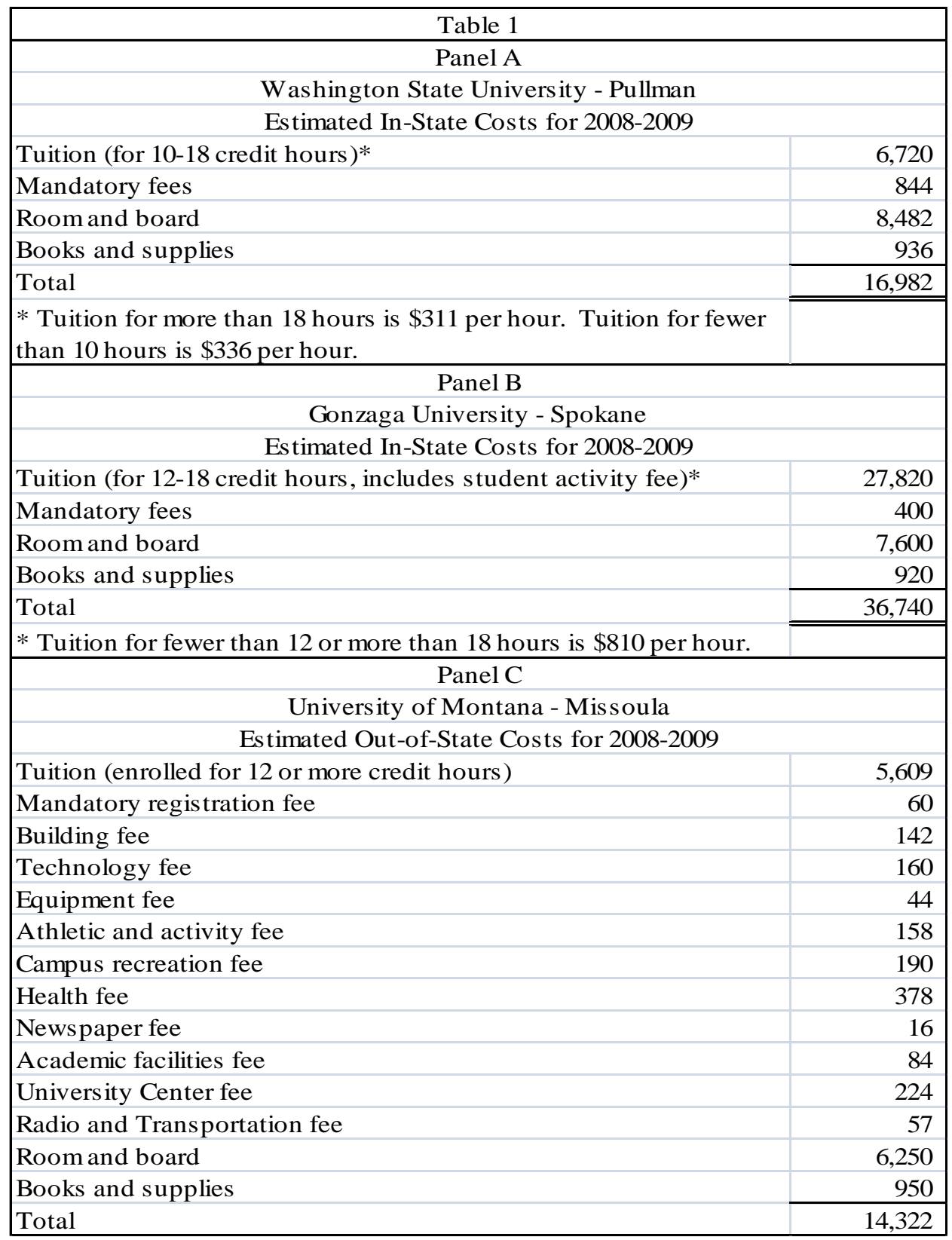

\section{INSTRUCTOR'S MANUAL}

\section{CASE OVERVIEW}

With this realistic case, we help students understand cost concepts and cost behavior patterns by using the college application process. A prospective student, Amy, considers three institutions of higher learning near her home in Spokane, Washington. She discovers that it can be very difficult to compare tuition and fees because colleges and universities base their charges on many different factors. Since most students have recently experienced Amy's struggle to make sense of financial information, they can often apply their personal knowledge to abstract managerial accounting concepts. In addition, we ask students to consider the cost concepts from another perspective, from that of university administrators setting tuition and fees. 


\section{LEARNING OBJECTIVES}

1. To enable students to define cost concepts by providing original examples from their own university experience.

2. To enable students to identify cost behavior patterns at both a personal level and for a university in total.

\section{COST CONCEPT QUESTIONS}

1. What is Amy's "relevant range" when registering for classes each term?

Amy's relevant range is the number of credits she will be taking. Because Amy is planning to enroll fulltime, her relevant range is 12 to 18 credit hours. See Figure 1 for a comparison of tuition costs for the three universities Amy is considering.

\section{Figure 1}

Tuition Costs Based on Credit Hour Enrollment at Gonzaga University, University of Montana, and Washington State University

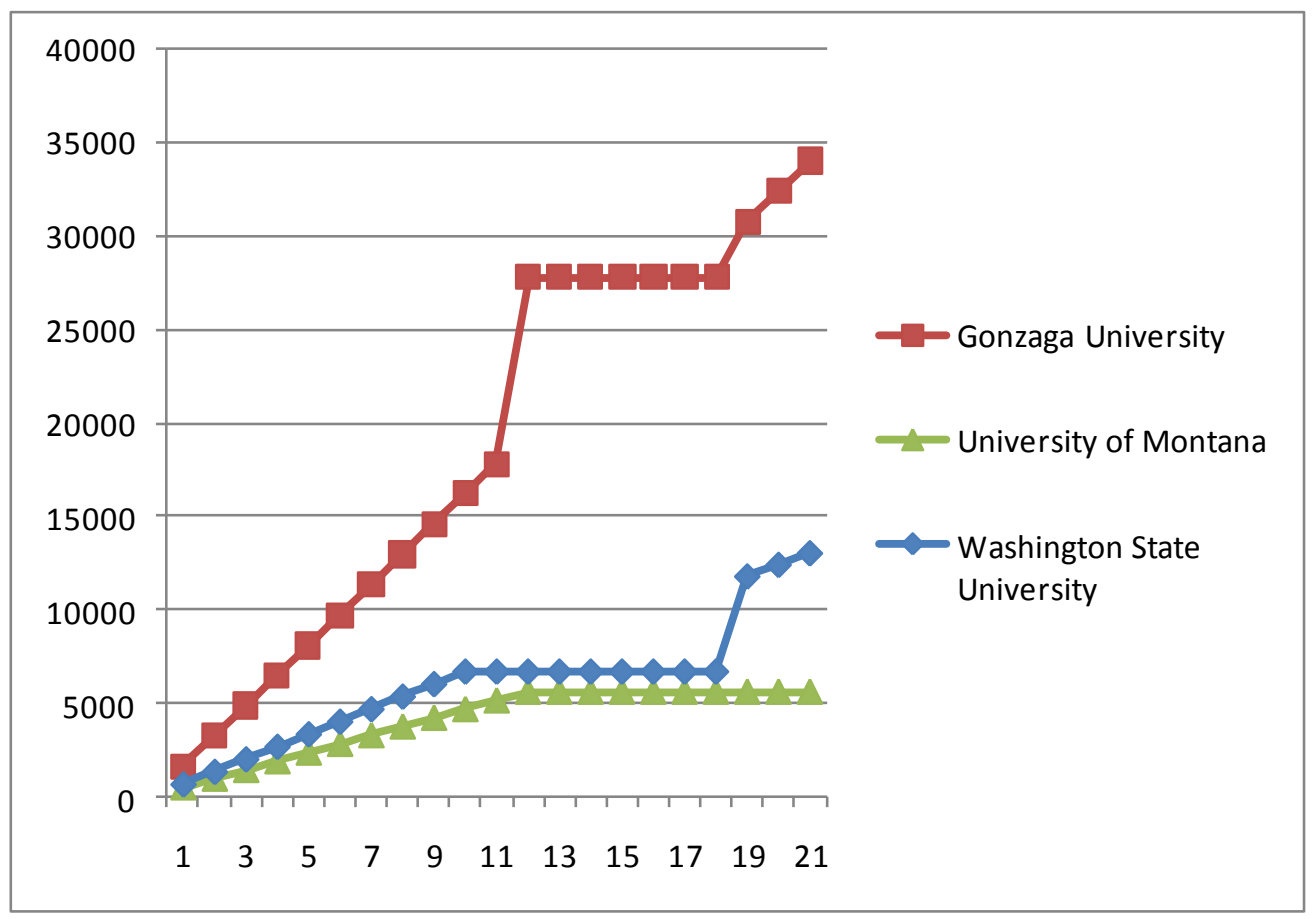

2. What is your university's "relevant range" regarding student enrollment?

Recent enrollment at the University of Montana has exceeded 14,000 students. The relevant range is therefore centered very closely to this figure. Significant drops in enrollment would affect state funding, while significant increases would be very difficult due to the limited physical resources on campus. The University adjusts capacity in the short term through the use of adjunct instructors and class size. Demand is indicated by a variety of factors, one of which is the number of students satisfactorily completing the prerequisites. The University adjusts for long term fluctuations by projecting future enrollments.

3. Define each of the following cost terms and give three examples that Amy can expect to encounter during her first year in college: 

a) variable cost
b) fixed cost
c) sunk cost
d) opportunity cost
e) direct cost
f) indirect cost
g) differential cost

a) Variable cost

Definition: cost that changes in total depending on activities

Examples: books (often related to number of credits taken since each class is likely to require at least one book), weekend activities (variable based on activities selected), gas (variable based on use of car)

\section{b) $\quad$ Fixed cost}

Definition: cost that does not change in total as activity levels change

Examples: health center fee (expense to student regardless of number of credit hours enrolled), meal plan (time period cost regardless of amount of food consumed), auto insurance (time period cost regardless of miles driven)

c) Sunk cost

Definition: money already spent that a student cannot recover

Examples: purchase of computer for school, application fees, school supplies

d) Opportunity cost

Definition: benefit given up by choosing one course of action over another

Examples: by going to school, students may forego 1) income from jobs at home, 2) home-cooked meals, 3) skiing time

e) Direct cost

Definition: cost easily identified with an activity or item

Examples: supplies for a particular class, gas for traveling home, meal plan

f) Indirect cost

Definition: cost that is difficult to identify with an activity or item

Examples: cost of cell phone, auto insurance, auto maintenance costs

\section{g) Differential cost}

Definition: cost difference between alternatives

Examples: difference between going to a movie in a theater or attending a free concert on campus, living at home or in the dorm, eating in off-campus restaurants or on-campus food service

\section{COST BEHAVIOR QUESTIONS}

1. Choose one of the three universities for Amy to attend. From Amy's point of view, indicate the typical cost behavior of the following costs (e.g., variable, fixed, mixed, step-fixed) using an appropriate independent variable:
a) tuition
b) the cost of a dorm room
c) food
d) books and supplies
e) fees
f) travel 
Amy should choose to attend the University of Montana because full-time enrollment for 15 credits per semester for an academic year is estimated to cost $\$ 14,322$, which is the lowest cost alternative under consideration. See Table 1 for details.

The following costs behave in the following manner:

a) Tuition is fixed in Amy's relevant range of 12 to 18 credit hours per semester

b) The cost of a dorm room is fixed per semester and unrelated to credit hours

c) Food is fixed according to the campus meal plan and unrelated to credit hours

d) Books and supplies are variable according to course requirements

e) Fees are fixed in Amy's relevant range of 12 to 18 credit hours per semester

f) Travel costs are variable according to the number of trips Amy makes home to Spokane and is unrelated to credit hours

2. Now that you have chosen a university for Amy in Cost Behavior Question \#1, take the university's point of view. Indicate the typical cost behavior of the following costs (e.g., variable, fixed, mixed, step-fixed) if the number of students enrolled in classes is used as the independent variable. Hint: what is the university's relevant range?

a) faculty payroll

b) utilities

c) food served by dining services

d) books and supplies sold in the bookstore

e) building maintenance

f) janitorial services

From the university's point of view, these costs would behave as follows:

a) Faculty payroll is a mixed cost because some faculty members are paid a salary while others are paid per course taught.

b) Utilities are variable depending on usage. During the winter, buildings are typically warmer during the hours of usage and cooler at unused times such as weekends.

c) Food served by dining services is variable depending on meals served.

d) Books and supplies sold in the bookstore are variable depending on sales.

e) Building maintenance is a mixed cost. Maintenance work done annually, such as painting parking lot spaces, is fixed. Maintenance performed on as "as needed" basis, such as repairing vandalism damage, is variable.

f) Janitorial services is a mixed cost. Janitorial work that is performed daily, such as cleaning classrooms, is fixed. Janitorial services such as cleaning up a football stadium is variable depending on the number of games.

3. What is the definition of a committed fixed cost? List three committed fixed costs encountered by a university.

A committed fixed cost is one that managers cannot reduce in the short term without compromising the long term goals of the organization. Examples include salaries of tenured faculty, facility maintenance costs, and salaries of administrators.

4. What is the definition of a discretionary fixed cost? List three discretionary fixed costs encountered by a university.

A discretionary fixed cost is one that managers can reduce in the short term without compromising the long-term goals of an organization. Examples include a contract with adjunct faculty, an advertising initiative, and a student summer recreation program. 
5. Suppose that after classes have started, a new student enrolls in your managerial accounting class (assume there was an extra seat). What is the incremental revenue to the university? What is the incremental cost?

Depending on the number of credit hours the student is taking, the student may be at a "flat spot" in the tuition scale. See Figure 1 for a graphic representation of no change in tuition within a relevant range of approximately 12 to 18 credit hours per semester for all three universities under consideration. Therefore, if a student is within the relevant range, the university will not gain any additional tuition revenue from enrollment in the managerial accounting class. Nor will the university incur significant additional costs from the additional enrollment. Most costs are fixed but there are incremental costs to consider. For example, a new student will require a copy of a syllabus, handouts, and exams throughout the semester. At five cents per page the printing costs could easily add up to $\$ 1.75$ per semester.

\section{CONCLUSION}

We tested this case in the classroom during Fall Semester 2007 using 2007-2008 tuition and fee information for the three institutions Amy was considering. A single instructor taught all sections of the managerial course during the term. She divided students in the four sections of the course into either the experimental group (two sections) or the control group (two sections). Regardless of group, all students completed the textbook homework problems assigned for the chapter covering cost concepts and the chapter covering cost behavior. They also completed both a pre-test and post-test quiz on terms and concepts from the related chapters. Students who participated in the study performed better on quizzes covering this material than students in the control group.

\section{AUTHOR BIOGRAPHIES}

Barbara Reider is a professor of accounting at the University of Montana where she holds a John and Kathy Connors Faculty Fellowship. Her teaching areas of interest include managerial accounting and auditing.

Belva Jones is an associate professor of information systems at the University of Montana. Her teaching specialty is project management.

Barbara Chaney is an associate professor of accounting at the University of Montana. Her teaching specialty is governmental and nonprofit accounting.

Kristen Sohlberg is a lecturer at the University of Montana. She teaches managerial and financial accounting.

\section{REFERENCES}

1. Accounting Education Change Commission, The First Course in Accounting: Position Statement No. Two, Issues in Accounting Education, Vol. 7, No. 2, pp. 249-251, 1992.

2. Garrison, R. H., E. W. Noreen, and P. C. Brewer, Managerial Accounting, Thirteenth edition, New York, NY: McGraw-Hill/Irwin, 2010. 


\section{NOTES}

